\title{
Sports training for primary and secondary school students. Training solutions in the context of digital transformation
}

\section{Entrenamiento deportivo para escolares de primaria y secundaria. Soluciones formativas en el contexto de la transformación digital}

\author{
Leng Thi Lan, Dinh Tran Ngoc Huy ${ }^{2 *}$, Thi Hang Nguyen ${ }^{3}$, Dinh Thi Hien ${ }^{4}$ \\ ${ }^{1}$ Thai Nguyen University of Agriculture and Forestry, Vietnam \\ ${ }^{2}$ Banking University HCMC, Ho CHi Minh city Vietnam - International University of Japan, \\ Niigata, Japan \\ ${ }^{3}$ Thai Nguyen University, University of Information and Communication Technology, Vietnam \\ ${ }^{4}$ Thai Nguyen University of Science, Vietnam \\ * Correspondence: Dinh Tran Ngoc Huy; dtnhuy2010@gmail.com
}

\begin{abstract}
The aim of this paper was to provide suggestions for good sports training and to help primary and secondary school students to improve their physical and mental health. It was also discussed the impact of digital transformation on students' sports training. The authors used qualitative analysis, synthesis and inductive methods. They also used experimental testing methods and experience. The authors consider physical education as a prerequisite for the development of other aspects of education. They explain the benefits of sports by stating that primary and secondary school students who participate in sports have the following benefits: they are healthier, they avoid the effects of technology and bad habits, they make friends, have fun, build social confidence, interact socially and learn to deal with failure. In conclusion, primary and secondary school students can successfully and safely improve their overall health by participating in a well-supervised sport training. Trained fitness professionals play an essential role in ensuring proper technique, form, progression of exercises, and safety in this age group.
\end{abstract}

\section{KEYWORDS}

Sports training; Digital technology in education; Children; Youth. 


\section{RESUMEN}

El objetivo de este trabajo fue aportar sugerencias para un buen entrenamiento deportivo y ayudar a los alumnos de primaria y secundaria a mejorar su salud física y mental. También se discutió el impacto de la transformación digital en la formación deportiva de los alumnos. Los autores utilizaron métodos cualitativos de análisis, síntesis e inductivos. También utilizaron métodos de prueba experimentales y experiencia. Los autores consideran la educación física como un requisito previo para el desarrollo de otros aspectos de la educación. Explican los beneficios del deporte afirmando que los alumnos de primaria y secundaria que practican deporte tienen los siguientes beneficios: son más saludables, evitan los efectos de la tecnología y los malos hábitos, hacen amigos, se divierten, generan confianza social, interactúan socialmente y aprender a lidiar con el fracaso. En conclusión, los estudiantes de primaria y secundaria pueden mejorar con éxito y seguridad su salud general participando en un entrenamiento deportivo bien supervisado. Los profesionales del fitness capacitados juegan un papel esencial para garantizar la técnica adecuada, la forma, la progresión de los ejercicios y la seguridad en este grupo de edad.

\section{PALABRAS CLAVE}

Entrenamiento deportivo; Tecnología digital en educación; Niños, Juventud

\section{INTRODUCTION}

Sport training has become a hot topic for teachers and students in schools in many countries (Siedentop et al., 2019; Olaosebikan et al., 2021). The sudden emergence of the pandemic COVID19 has brought opportunities and risks, and has significantly affected the development and operation of educational institutions. Like many other sectors, educational activities have also been affected by the covid-19 pandemic in the recent period. The transition from face-to-face to online learning puts a lot of pressure both on teachers and students. In addition, the requirements of high consciousness and concentration on the internet environment make many children feel unfamiliar, anxious, distracted, and psychologically stressed. Many educational plans and activities aimed at skill development, communication, and exercise activities are limited. Sports tournaments and outdoor educational activities have been postponed or modified.

In order to minimize the impact of the epidemic, it is necessary to immediately establish a plan to adjust activities so that educational institutions can gradually adapt and "live together" with the epidemic. Especially in sports activities, training schedules must be adapted to the current conditions and the team must be optimally prepared so that after everything returns to normal, the new athletes 
can participate in the tournament in good shape and achieve good results (Siedentop et al., 2019; Olaosebikan et al., 2021).

Moreover, we have no scientific evidence yet that the COVID-19 pandemic causes mental changes. But in fact, many people due to limited social communication have led to mental illnesses, affecting human psychology. The fact that people have to practice social distancing and restrict communication has become factors that exert strong psychological pressure on many sections of society, including children. Children are among the sensitive people who are easily affected by the COVID -19 epidemic. Therefore, in order to prevent COVID -19 and limit the stress and pressure to which children are exposed, to minimize the impact of psychological pressure on the lives, activities and social interactions of learners, especially children, home activities need to be increased. Measures are needed to proactively overcome the effects of COVID -19. Students should normalize their anxiety by having more conversations with their relatives and participating in sports and recreational activities. The practice of sports creates physical strength, helps in the development, prevention and restoration of bodily functions. This can be applied to all age groups. Especially in the current era, where there are many problems with obesity and postural defects in children, it is necessary to apply specialized sports such as swimming, badminton, running. These sports help to train the strength of the body. These exercises help to increase bone density and help to treat osteoporosis effectively. In addition, other exercises such as strength training help to prevent and reduce the risk of injury in other sports activities (Ruffault et al., 2020; Ozrudi et al., 2021).

\section{LITERATURE REVIEW}

The diversification of education types not only helps to increase the thinking ability but also increases the ability to develop comprehensively the cognitive aspects, including the physical body. In the context of increasing digital transformation, enhancing skills training for learners through the application of digital technologies plays an important role. The issue of attaching importance to moral and physical education towards comprehensive human development, also plays an important role. Therefore, it is necessary to ensure a safe and healthy workplace for the staff, scientific, technical, spatial and, above all, organizational and administrative conditions for sports training. Sports training is a rather specific concept, which aims to train the skills specific to a particular sport. The main goal of sports training is not to achieve great success, but for learners to gain more selfknowledge through sports training. At the same time, learners improve their learning ability and become equipped with a broad base of motor skills that are not limited to specific movements in a given sport field. 
Ensuring the conditions of personnel, science, technology, and facilities for sports training courses plays an extremely important role. This is clearly expressed in Directive 36/CTTW of the Central Committee of the Communist Party of Vietnam on "Strengthening Physical Training and Sports in the New Period". It is necessary to focus on improving the organization and management of physical education and sports activities, in the direction of closely linking State organizations and social organizations. In this basis, creating conditions for staff, facilities and science and technology to rapidly develop a number of traditional and promising Vietnamese sports play a particularly important role. For every learner, the development of physical training and sports is an objective requirement to contribute to the improvement of health, fitness and quality of life. At the same time, it contributes to improving the quality of human resources, educating the will and morality, building a healthy lifestyle and cultural environment to ensure the development of physical training and sports. This is also clarified in Resolution No. 08-NQ/TW dated December 1, 2011 of the Politburo on "Strengthening the leadership of the Party, creating a strong development in physical training and sports until 2020".

Scholars such as Novicop, Matveep (Russia); Harre (Germany); Dien Mai Cuu, Ly Van Tinh (China) consider teaching aids and tools very important in teaching and technical training of sports for learners, especially children. It is an activity that provides the means of imparting and improving the quality of sports teaching for learners. The current context of digital transformation and the current explosion and strong development of digital technologies have created opportunities to support teaching activities with additional teaching tools and virtual interaction. This will make an important contribution, improve efficiency and shorten the process of completing sports practice for learners in general and for children in particular.

Ostrowski et al. (2009) found that the Applied Sport Psychology educational intervention for athletic trainers increased knowledge of the psychology of injury (29-point increase from baseline to intervention week 6; F2,23 = 29.358, P <.001, $\eta \mathrm{p} 2=0.719)$ and skill usage (50-point increase from baseline to intervention week $6 ; \mathrm{F} 2,23=5.999, \mathrm{P}=.008, \eta \mathrm{p} 2=0.343$ ) in undergraduate ATSs. These increases were maintained at the 7 - and 14-week tests ( $\mathrm{P}<.001$ for both). And move on to the conclusions: the first attempt to evaluate an educational intervention designed to improve ATSs knowledge and skill use showed that the intervention was effective. Although knowledge and skill use scores decreased at the end of the retention period, scores were still higher than baseline, indicating that the intervention was effective.

Carter \& Micheli (2011) state that the combination of increased exertion and decreased preparation for sports participation has led to an epidemic of acute and chronic sports-related injuries 
in this population. Poor physical fitness appears not only to have negative health consequences, but also to be a risk factor for sports-related injuries. Initial experience with several specific injury patterns-anterior cruciate ligament injuries and ankle sprains has demonstrated the effectiveness of such targeted prevention strategies.

\section{METHODS}

The aim of the present study was to provide suggestions for good sports training and help primary and secondary school students to improve their physical and mental health. Also, it was discussed the impact of digital transformation on students' sports training. With this purpose, the method used in this research was qualitative analysis, combined with synthesis and inductive methods and explanatory research. The process of analysis was carried out using historical information and methods of historical and dialectical materialism. The authors also used experimental testing methods and experience. Through the study, the authors aim to provide suggestions for good sports training and to improve physical and mental health of primary and secondary school students.

\section{RESULTS}

The characteristics of sports training programs for primary and secondary school students are explained in the following table (Table 1).

Table 1. Characteristics of sports training programs for primary and secondary school students

\begin{tabular}{|c|c|c|}
\hline & Primary school students & Secondary school students \\
\hline \multirow[t]{6}{*}{ Requirements } & $\begin{array}{l}\text { Technique: dribbling while changing direction and } \\
\text { changing dribbling speed. }\end{array}$ & $\begin{array}{l}\text { Technique: dribbling while maintaining a } \\
\text { normal posture. }\end{array}$ \\
\hline & $\begin{array}{l}\text { Physical requirements: balance, coordination, } \\
\text { fitness. }\end{array}$ & $\begin{array}{l}\text { Physical requirements: adapting to different } \\
\text { postures, balance, agility, strength. }\end{array}$ \\
\hline & $\begin{array}{l}\text { Social development: training with a teammate. } \\
\text { Physical requirements: reaction time, coordination, } \\
\text { balance. }\end{array}$ & $\begin{array}{l}\text { Social development: showing enjoyment, } \\
\text { accepting challenges, knowing how to work as } \\
\text { part of a team. }\end{array}$ \\
\hline & $\begin{array}{l}\text { Social development: grouping with different } \\
\text { players, not just a best friend. }\end{array}$ & $\begin{array}{l}\text { Technical: dribbling, covering, blocking. } \\
\text { Physical requirements: balance, agility, fitness. }\end{array}$ \\
\hline & Tactics: finding players, moving quickly. & $\begin{array}{l}\text { Social development: assertiveness, success, } \\
\text { team consensus. }\end{array}$ \\
\hline & & Tactics: one on one. \\
\hline $\begin{array}{l}\text { Nutrition, food } \\
\text { and drinks }\end{array}$ & $\begin{array}{l}\text { When children are playing sports, mothers should } \\
\text { pay attention to their children's diet so that they } \\
\text { consume enough calories, carbohydrates, proteins, }\end{array}$ & $\begin{array}{l}\text { When it comes to fueling yourself before or } \\
\text { after a workout, you need to find the right } \\
\text { balance between classes of substances. Pre- }\end{array}$ \\
\hline
\end{tabular}


iron, vitamins and other minerals. An active lifestyle, regular exercise and proper nutrition help children grow up healthy. Children between the ages of 5 and 12 often like to play competitive sports and want to be physically fit so they can run faster or throw a stronger ball. However, there are no magic foods or supplements that can transform a child from an average athlete into a superstar. Still, a well-balanced, nutrient-dense diet for children can partially meet a child's needs for physical activity and rest.

If your child participates in a lot of sports, make sure to provide the child's body with some essential nutrients such as calories, carbohydrates, protein, iron, vitamins, other minerals, and fluids. workout snacks that combine carbohydrates with unsaturated fats will help you feel more energized and work out more efficiently. After your workout, protein-packed foods are a great way to help your muscles recover and grow.

Split meals: If you work out every day but only eat 3 main meals: Breakfast - Lunch - Dinner, you will definitely feel hungry and low on energy. So, divide your energy intake into several meals during the day. This will also help you feel better, absorb nutrients better and improve sport performance.

Next, we analyze some types of sports games, with their advantages for primary and secondary school students (Table 2).

Table 2. Advantages of sports games

\begin{tabular}{ll}
\multicolumn{1}{c}{$\begin{array}{c}\text { Sport } \\
\text { games }\end{array}$} & \multicolumn{1}{c}{ Primary school students } \\
\hline Volleyball & $\begin{array}{l}\text { Lose weight and fat is another advantage of } \\
\text { volleyball. }\end{array}$ \\
& $\begin{array}{l}\text { Another advantage that volleyball brings in } \\
\text { losing weight is that the ratio of muscle and fat } \\
\text { is better distributed and maintained for a long } \\
\text { time. This is especially important for } \\
\text { professional athletes. However, if you only play } \\
\text { for entertainment and weight loss, volleyball is } \\
\text { a sport not to be missed. }\end{array}$
\end{tabular}

Secondary school students

When playing, the ball moves at a very fast speed, so players must skillfully coordinate their hands and eyes to keep up. Players must not only watch and catch the ball, but also quickly determine the tactics and direction of the ball in order to make the best quality pass.

When hitting the ball, the only thing you need to do is determine the right time, ball position and hand strength so that the opponent does not have time to return. When defending, the eye should always be on the ball to have appropriate countermeasures. Whether on the offensive or defensive, over time your reflexes will also improve significantly.

Soccer Benefits: Lose weight, fat and become healthier.

Improve heart health

Build friendships

Learn how to win and lose

Learn to play as a team

Have more self-respect

The benefits of football for us are improved heart health and a lower risk of high blood pressure of football players. This is because when playing football, there will be a continuous change of focus in the middle of the arm, turning the head, running which helps the heart to work stably, be healthy and have a balanced physique.

Teach hard work, dedication and discipline

Build character and individuality

Live happier

Learn respect

Enjoy the taste of the match

Compete all over the world

Increase competition in a healthy way 
Burn fat and calories

The benefits of football also help us lose weight and reduce fat through combined full-body exercises such as jogging, joint rotation, along with general strength exercises. As can be seen, while kicking the ball, the whole body is active and this is very beneficial for improving the perfect body.

\begin{tabular}{|c|c|c|}
\hline Badminton & $\begin{array}{l}\text { Benefits: Lose weight, fat and become more } \\
\text { flexible. } \\
\text { Physical strength } \\
\text { Running, jumping and swinging badminton } \\
\text { burns fat at a rate of } 450 \text { calories/hour. } \\
\text { Badminton is a very effective cardio } \\
\text { (cardiovascular) workout that helps you } \\
\text { improve your physique, especially if you chose } \\
\text { to combine it with another sport. } \\
\text { Mental improvement } \\
\text { Playing badminton increases the amount of } \\
\text { endorphins, hormones that help people feel } \\
\text { happy, love life, think positively and sleep well. } \\
\text { Badminton also helps to reduce stress and } \\
\text { anxiety as it improves physical health. }\end{array}$ & $\begin{array}{l}\text { Enhanced speed, reflexes } \\
\text { Badminton requires speed, so this sport will help } \\
\text { you improve your speed and reflexes. Sharpness is } \\
\text { also an important factor because players must } \\
\text { know how to deceive their opponents. } \\
\text { Increase muscle strength } \\
\text { Playing badminton strengthens quadriceps, glutes, } \\
\text { calves and hamstrings. At the same time, the main } \\
\text { muscles in your body such as the biceps and back } \\
\text { are also affected quite strongly. }\end{array}$ \\
\hline $\begin{array}{l}\text { Motorbike, } \\
\text { Bike }\end{array}$ & \multicolumn{2}{|c|}{$\begin{array}{l}\text { Biking is the ideal sport for exercising physical health, while for the youth, motorbike and conquest } \\
\text { racing is preferred because of the feeling of racing behind the wheel on challenging tracks, or the } \\
\text { moment when they reach the finish line to the cheers of fans. In this way, speed lovers also show } \\
\text { strength, pride and class. However, racing is undeniably a very risky sport and requires serious } \\
\text { investment. This means that you need to be really passionate and brave to pursue it to the end. }\end{array}$} \\
\hline
\end{tabular}

\section{DISCUSSION}

Taking into account these results, we suggest ideas for building sports training programs for primary and secondary school students. Teaching in general, and sports teaching and training in particular, is an integrated science, aimed at comprehensive human development. The development and explosion of digital technology has greatly supported physical education. Therefore, physical education teaching and training programs in countries with developed science and technology have constantly renewed and improved their quality by diversifying the practical and experimental tools in the virtual space. This helps learners to become familiar with the virtual interactions before practicing in the real space. Therefore, for effective teaching activities, it is necessary to develop appropriate programs, which clearly specify theoretical and practical contents. In particular, the use of tools that allow learners to experience manipulations and movements through simulation technology. From there, you can help learners become familiar with the content, forms and methods of training. 
The development of a sports training program plays an important role. This is the basic framework for implementing future teaching scenarios. Therefore, it is necessary to develop a sports training program that is adapted to practical conditions and has technological interactions. The program must be responsive to and throughout the training process. This program must list all the contents, from the stage of enrollment, formation of teaching staff, training and conditions to meet the qualifications of teachers, coaches, facilities, training ground exercise tool. All this must be evident in the training facilities of the clubs, sports centers or arenas. An equally important issue in the design of a sports training program is the formation of the quality assessment stage of the programmes, teaching and training plans. This stage must ensure efficiency and be executed in a methodical and professional manner.

Appropriate sports training programs can produce several benefits for primary and secondary school students:

- Strengthening health: the first and most obvious benefit of exercise training is to increase health, increase endurance and flexibility, agility. That is why this subject this subject is indispensable on the way to full development both physically and mentally.

- Increase team spirit: sports activities at school help students increase team spirit, better integrate into groups and collectives, enhance exchanges and connections, especially between friends who share a common passion.

- Increase discipline: exercise and sports require quite high discipline to be effective.

Our results can also be analyzed in the context of Ho Chi Minh ideologies for sports and physical exercises. President Ho Chi Minh pointed out that "Under democracy, sports and physical education must become common activities of the masses, aiming to enhance the people's health. If the people are healthy, everything can be done well". He encouraged: "So exercising, improving health is the duty of every patriotic citizen". Since then, Ho Chi Minh has advocated: "We should develop the sports movement widely". These are the general views of Ho Chi Minh about mass sport and sport for everyone. Regarding physical education for school youth, Ho Chi Minh identified this as an important part of the national education of an independent and democratic Vietnam (Minh, 2021). The COVID-19 pandemic has turned pressure into a driving force for digital transformation in the education sector. The context of digital transformation is also leading to huge changes in the way things are done in the new environment rather than using the old methods in the new environment. The complicated situation of the Covid-19 epidemic, has led to the implementation of the policy of social distancing to limit the spread and spread of the disease. As a result, children stopped going to 
school, gyms and sports facilities were closed. To continue to settle into the new normality, to help students stop going to school but also stop learning, it is necessary to diversify the types of activities. In parallel with student learning, to reduce pressure and stress of limiting communication with others, it is necessary to diversify the types of activities. Diversifying the types of activities, especially practicing sports, creates balance and reduces psychological pressure. This article focused on the objective necessity of applying technological solutions to develop skills and balance the psychological state of learners to adapt to the pandemic context. In this context, it is especially important to analyze the current situation and propose ideas and solutions to improve educational activities for learners to both adapt to the increasing pandemic and take advantages of the technology platform to increase educational effectiveness.

Huy et al. (2021) mentioned the important role of teachers in training and teaching quality solutions in schools in the new era. For example, Dahab \& McCambridge (2009) found that children can improve their strength by 30 to $50 \%$ after only 8 to 12 weeks of a well-designed strength training program. Therefore, it is very important that in this new era youth continue to train at least 2 times per week to maintain their strength. In order to prevent injuries related to strength training, including epiphyseal plate fractures and lower back injuries, it should be avoided the misuse of equipment, inappropriate weight, improper technique, or lack of qualified adult supervision. Young athletes and non-athletes alike can successfully and safely improve their strength and overall health by participating in well-supervised programs. Finally, it is necessary that these programs are supervised by trained fitness professionals to ensure the use of proper technique, adequate progression of exercises and safety.

\section{REFERENCES}

1. Carter, C. W., \& Micheli, L. J. (2011). Training the child athlete: physical fitness, health and injury. British Journal of Sports Medicine, 45(11), 880-885. https://doi.org/10.1136/bjsports$\underline{2011-090201}$

2. Dahab, K. S., \& Mccambridge, T. M. (2009). Strength Training in Children and Adolescents. Sports Health, 1(3), 223-226. https://doi.org/10.1177/1941738109334215

3. Huy, D. T. N., Van, P. N., \& Ha, N. T. T. (2021). Education and computer skill enhancing for Vietnam laborers under industry 4.0 and EVFTA agreement. Elementary Education Online, 20(4), 1033-1038. 
4. Hien, D. T., Huy, D. T. N., \& Hoa, N. T. (2021). Ho Chi Minh Viewpoints about Marxism Moral Human Resource for State Management Level in Vietnam. Psychology and Education, 58(5), 1553-6939.

5. Dung, V. T. T., Nuong, L. N., Huy, D. T. N., Thach, N. N., \& Thuy, N. T. (2021). Enhancing the capabilities of students after graduation - a case study at university of economics and business administration - thai nguyen university, Vietnam. Elementary Education Online, 20(4), 592-599.

6. Huy, D. T. N., Hanh, N. T. T., Hang, N. T., Nhung, P. T. H., Thao, N. T. P., Han, L. T., \& Sang, D. T. (2021). General solutions for enhancing quality of teachers during globalization in emerging markets including Vietnam-and some pedagogy psychological issues. Psychology and Education, 58(4), 2343-2349.

7. Huy, D. T. N. (2015). The critical analysis of limited south asian corporate governance standards after financial crisis. International Journal for Quality Research, 9(4), 741-764.

8. Huy, D. T. N. (2012). Estimating beta of vietnam listed construction company groups during the financial crisis. Journal of Integration and Development, 15(1), 57-71. https://doi.org/10.15458/2335-4216.1184

9. Huy, D. T. N., Dat, P. M., và Anh, P. T. (2020). Building and econometric model of selected factors' impact on stock price: a case study. Journal of Security and Sustainability Issues, 9(M), 77-93. https://doi.org/10.9770/jssi.2020.9.M(7)

10. Huy, D. T. N., \& Hien, D. T. N. (2010). The backbone of European corporate governance standards after financial crisis, corporate scandals and manipulation. Economic and Business Review, 12(4), 215-240. https://doi.org/10.15458/2335-4216.1254

11. Huong, L. T. T., Huong, D. T., Huy, D.T.N., \& Thuy, N. T. (2021). Education for students to enhance research skills and meet demand from workplace - case in vietnam. Elementary Education Online, 20(4), 606-611.

12. Ostrowski, J. L., Gould, D. R., \& Covassin, T. (2009). An evaluation of an educational intervention in psychology of injury for athletic training students. Journal of Athletic Training, 44(5), 482-489. https://doi.org/10.4085/1062-6050-44.5.482

13. Hoa, N. T., Hang, N. T., Giang, N. T., \& Huy, D. T. N. (2021). Human resource for schools of politics and for international relation during globalization and EVFTA. Elementary Education Online, 20(4), 2448-2452. 
14. Hong, N. B., Huy, D. T. N., Ha, L. T., \& Nam, V. Q. (2021). Education issues for students in accounting major with case teaching method at accounting faculty in universities and postgraduate levels. Journal for Educators, Teachers and Trainers, 12(2), 62-70.

15. Dat, P. M., Mau, N. D., Loan, B. T. T., \& Huy, D. T. N. (2020). Comparative China corporate governance standards after financial crisis, corporate scandals and manipulation. Journal of Security \& Sustainability Issues, 9(3), 931-941. https://doi.org/10.9770/jssi.2020.9.3(18)

16. Tram, P. N., \& Huy, D. T. N. (2021). Educational, Political and Socio-Economic Development of Vietnam Based on Ho Chi Minh's Ideology. Elementary Education Online, 20(1), 1238-1246. https://doi.org/10.17051/ilkonline.2021.01.125

17. Thi, T. D. V., Thu, T. N. M., Huy, D. T. N., \& Thuy, N. T. (2021). Effects of western culture and ho chi minh ideology on Vietnam education. Elementary Education Online, 20(4), 612616.

18. Olaosebikan, B. T., Ibrahim, A. B., \& Abdullahi, A. (2021). Influence of school location in the implementation of secondary schools physical education curriculum in Nigeria. Journal of Humanities and Social Sciences, 1(2), 63-76.

19. Minh, H. C. (2021). BaoQuangBinh. https://www.baoquangbinh.vn/

20. Siedentop, D., Hastie, P., \& Van der Mars, H. (2019). Complete guide to sport education. Human Kinetics.

21. Ozrudi, M. F., Yaghobi, A., Zorofian, M., \& Teymorinezhad, Z. (2021). The role of out looking hope of the physical education lecturers in predicting the happiness and self-efficacy of the students due to covid-19. Journal of Specific Sport Science, 1(2), 1-8.

22. Ruffault, A., Bernier, M., Fournier, J., \& Hauw, N. (2020). Anxiety and motivation to return to sport during the French COVID-19 lockdown. Frontiers in Psychology, 11, 610882. https://doi.org/10.3389/fpsyg.2020.610882

\section{AUTHOR CONTRIBUTIONS}

All authors listed have made a substantial, direct and intellectual contribution to the work, and approved it for publication.

\section{CONFLICTS OF INTEREST}

The authors declare no conflict of interest.

\section{FUNDING}

This research received no external funding.

\section{COPYRIGHT}

(C) Copyright 2022: Publication Service of the University of Murcia, Murcia, Spain. 